\title{
EVALUATION OF YIELD AND QUALITY TRAITS OF FOURTEEN CULTIVARS AND PROMISING LINES OF EGYPTIAN COTTON
}

(Received: 12. 2. 2012)

\author{
By \\ I. A. M. Ebaido, H. S. A. Fateh* and R. M. Hassan \\ Cotton Research Institute, * Center Laboratory of Design and Statistical Analysis Research, Agriculture \\ Research Center, Giza, Egypt
}

\begin{abstract}
The main objective of this study was to evaluate the lint cotton yield and the quality characteristics of some Egyptian cotton commercial varieties and promising lines in the advanced strain test (Trial B) during a period of five years, from 2006 to 2010 seasons. Fourteen cotton genotypes representing the two Egyptian cotton categories: extra-long staple (ELS) and long staple (LS) were evaluated for lint cotton yield, micronaire value, fiber length, fiber strength and yarn strength. There were wide ranges and symmetric distributions for most of these traits.

Analysis of variance depicted considerable mean squares for cotton yield and fiber quality traits due to cotton genotypes, years and cotton genotype $\times$ year interaction. The promising lines derived from the hybrids G.84 × $(\mathrm{G} .70 \times$ G.51B $) \times \mathrm{S} 62$ and $10229 \times$ G.86 achieved the desirable demands of high yield and quality. There were significant correlation coefficients among yield and quality traits; these correlations would be employed as selection criteria for successful cotton breeding. Correlations reveal that any improvement in micronaire (low value), fiber length and fiber strength may decrease cotton yield and increase yarn strength. Development of cotton varieties with improved fiber traits has been very difficult due to the linkage among the genes controlling these traits, which can be avoided using new tools of molecular markers.
\end{abstract}

Key words: cotton yield, evaluation, fiber quality traits, Gossypium barbadense.

\section{INTRODUCTION}

Cotton, the main cash crop in Egypt, is the basis of national textile industry and a major source of foreign exchange and hence contributes substantially to the national economy. The Egyptian cottons enjoy a well deserved reputation for high quality. This achievement represents continuous concerted efforts to develop high yielding varieties with improved fiber quality. Cotton, like all commodities, is differentiated by quality parameters for the purposes of trade. Although many types of cotton can substitute for each other in various products, their distinct characteristics prevent them from being perfect substitutes. Buyers may value various attributes differently, depending on the final product and the production technology being used (Estur, 2004).

Development of cotton varieties that produce both high yields and excellent fiber quality has long challenged cotton breeders. Consistent high yields of varieties are hampered by annual variation in the environment-challenging breeders to find types that are able to yield well across highly contrasting environments. Fiber quality is also affected by variation in the environment, but probably hampered more by poor associations with high yield, the relative breeding priority on yield, and by changing definitions of excellent quality.

The major factor limiting breeding progress for better combinations of yield and fiber quality is the negative genetic association of yield and fiber quality. Meredith (2003) reported that increases of one unit (from 4.0 to 5.0) in micronaire value are expected to result in yield increase of about $90 \mathrm{Ib}$ lint/acre. On the other hand, an increase in upper half mean length (UHM) by one $\mathrm{mm}$ and an increase in HVI strength by $2 \mathrm{~g} /$ tex would be expected to be accompanied by a yield decrease of $8 \mathrm{Ib}$ and $29 \mathrm{Ib}$ of lint / acre, respectively.

Factors involving changes of environment, such as location, date of opening, or year of growth cause wide variation in yield and fiber quality. In this respect, Abdel-Latif et al. (1975) and Ismail and El-Sheikh (1991) reported that the differences in yield and fiber properties within a 
variety from year to year are greater than those between two varieties at the same location in the same year. Killi et al. (2005) stated that fiber quality properties showed high association with cotton yield. So, successful selection can be made on these characteristics for cotton yield.

Selection of superior genotypes for lint yield in cotton performance trials is impacted by genotype $\times$ environment interaction $(\mathrm{G} \times \mathrm{E})$. This impact is to a less degree for fiber quality (Campbell and Jones, 2005 and Paterson et al., 2003). Cotton fiber quality is defined by the physical properties that relate to its spinnability into yarn and contribute to textile performance and quality (Chee et al., 2005). One of the most important aspects of cotton fiber quality is fiber length that is directly related to yarn count, strength and spinning efficiency (Moor, 1996). Fiber fineness is another important character of fiber quality because of its direct impact on processing performance and yarn quality. Finer mature fibers can be spun with more fibers per cross- section, resulting in stronger and better quality yarns (Bradow and Davidonis, 2000). Fiber strength is important because the inherent breaking strength of individual cotton fibers is considered to be the most important factor in determining yarn strength (Moor, 1996). Fiber strength, micronaire and fiber length are closely and significantly correlated such that cultivars with longer fibers have stronger fiber and lower micronaire (Asif et al., 2008, Ulloa and Meredith, 2000 and Zhang et al., 2005). The analysis of California cotton performance trials by Geng et al. (1987) revealed that high yielding genotypes showed a decreased genotype stability for lint yield and genotypes with higher average fiber quality scores showed an increase in genotype stability for fiber quality.

Lint yields in 2010 season of Egyptian cotton were mixed and disappointingly low in many production areas. Fortunately, lint quality did not follow this trend.

The objective of this study was to examine the variation in lint cotton yield and fiber quality traits; and to determine an essential factor in developing improved combinations of cotton yield and fiber quality, if the association of yield and major fiber traits had been modified by five years of breeding.

\section{MATERIALS AND METHODS}

The present investigation included six commercial varieties and eight promising lines of Egyptian cotton (Gossypium barbadense L.).
These cottons were grown in the Advanced Strain Test (Trial B) in regions of North Delta, Central and Southern Delta and Upper Egypt for five successive years, 2006 through 2010, as follows:

1-Six genotypes that belong to the extra- long staple category (ELS) grown in North Delta: Giza 87, Giza 70, Giza 88, Giza 92, G.77 × S6 and G. $84 \times($ G. $70 \times$ G.51 B $) \times$ S62.

2-Four genotypes belonging to the long staple category (LS) grown in Central and Southern Delta: Giza 86, G.89 × G.86, G.75 × Sea and $10229 \times$ G. 86 .

3-Four genotypes belonging to the long staple category (LS) grown in Upper Egypt: Giza 80, Giza 90, G.90 × Australian and G.83 × (G.75 × $5844) \times$ G.80.

All commercial cotton varieties and promising lines were evaluated for lint cotton yield (LY) in Kentar per Feddan (K/F); and High Volume Instrument (HVI) was used according to ASTM (D: 1776-98) to determine fiber quality characteristics, i.e., fiber length expressed as upper half mean length (UHM) in millimeter $(\mathrm{mm})$, fiber strength at $1 / 8$ inch gauge in gram per tex $(\mathrm{g} / \mathrm{tex})$ and micronaire value (MIC). Yarn strength quoted as the product of "Lea strength in pound $\times$ yarn count "using the Good Brand Lea Tester (60s carded and 3.6 twist multiplier) according to ASTM (D: 1578 -67).

All tests were conducted at the laboratories of the Cotton Research Institute (CRI), Agricultural Research Center (ARC) in Giza, Egypt. The mean values of lint yield, fiber length, fiber strength, micronaire value and yarn strength were estimated for five years used to compare the tested cotton genotypes according to the final results of the statistical approach used in this investigation. Data gathered were computed using Minitab $^{\mathrm{TM}} 15$ software (Minitab, Inc., State College, PA) for the analysis of variance of yield and quality properties and person correlation coefficients among these traits.

\section{RESULTS AND DISCUSSION \\ 3.1. The extra-long staple cottons (ELS)}

The extra-long staple cottons are usually assigned to the Northern and Central Delta. The commercially grown varieties were used as standards for comparisons with promising lines.

As shown in Table (1), variations in lint cotton yield, the three main fiber- related traits and yarn strength were observed among 6 cotton genotypes across 5 years. The data showed wide ranges for all traits. Each property's median and mean values 
Table (1): Effect of cotton varieties and years on the means of yield and fiber yarn quality traits for the extra- long staple category.

\begin{tabular}{|c|c|c|c|c|c|}
\hline Cotton genotypes & $\begin{array}{c}\mathbf{L Y} \\
(\mathbf{K} / \mathbf{F})\end{array}$ & MIC & $\begin{array}{l}\text { UHM } \\
\text { (mm) }\end{array}$ & $\underset{(\mathrm{g} / \mathrm{tex})}{\mathbf{F}}$ & YS \\
\hline G.77 × S6 & 10 & 3.1 & 36.5 & 46 & 3170 \\
\hline G.92 & 11 & 3.4 & 34.1 & 47.5 & 3045 \\
\hline G.84×(G.70×G.51B $) \times$ S62 & 13.2 & 3.7 & 35.6 & 48.4 & 3160 \\
\hline G.87 & 8.9 & 3.2 & 35.9 & 45.8 & 3090 \\
\hline G.70 & 9.3 & 3.8 & 34.8 & 45.7 & 2925 \\
\hline G.88 & 10.7 & 3.8 & 35.4 & 47.3 & 3065 \\
\hline Mean & 10.4 & 3.5 & 35.4 & 46.7 & 3090 \\
\hline Median & 10.4 & 3.5 & 35.5 & 46.6 & 3075 \\
\hline \multicolumn{6}{|l|}{ Mean squares for } \\
\hline Cottons (V) & $11.01^{* *}$ & $\mathbf{0 . 1 1 3}^{* * *}$ & $0.57^{* * *}$ & $25.78^{* * *}$ & $122887^{* *}$ \\
\hline Years $(Y)$ & $10.65^{* * *}$ & $0.504^{* * *}$ & $3.44^{* * *}$ & $5.25^{* *}$ & $28014^{* * *}$ \\
\hline $\mathbf{V} \times \mathbf{Y}$ interactions & $0.22^{\mathrm{ns}}$ & $\mathbf{0 . 0 3 3}^{*}$ & $0.127^{*}$ & $0.577^{\mathrm{ns}}$ & $3027^{*}$ \\
\hline L.S.D. (0.05) & 0.612 & 0.086 & 0.258 & 0.576 & 35 \\
\hline
\end{tabular}

*, **: significant at $\mathbf{p}<0.05$ and $\mathbf{p}<0.01$ levels, respectively, while ns: non significant.

for lint yield (LY), micronaire value (MIC), fiber length (UHM) and fiber strength are approximately the same, indicating symmetric distributions of these values for extra-long staple varieties and promising lines. Whereas the differences between the median and mean for yarn strength (YS) would indicate a positively skewness distribution. The newly developed line derived from the hybrid G.77 $\times$ S6 had the finest and the longest fibers and produced the strongest yarns. Giza 70 showed shortcoming of UHM, LY, FS and YS. The promising line derived from the hybrid G. $84 \times($ G. $70 \times$ G. 51 B $) \times$ S62 achieved the desirable demands of high cotton yield and fiber and yarn quality.

The analysis of variance for yield, lint and yarn quality traits of cotton across 5 years indicated that there were highly significant differences $(\mathrm{p}<$ 0.01 ) among cottons and through the years. Whilst the variance ratio of variety $\times$ year interaction was reduced to a significant level $(p<0.05)$ for micronaire value, fiber length and yarn strength. Lint yield and fiber strength showed non significant variances due to $\mathrm{V} \times \mathrm{Y}$ interactions.

\subsection{The long staple cottons (LS)}

The long staple cottons are usually grown in Central and Southern Delta and Upper Egypt. The commercially grown variety Giza 86 was used as a standard comparison, representing Delta cottons. Giza 80 and Giza 90 were used as standards representing Upper Egypt cottons. The averages and analysis of variance for yield, fiber and yarn quality traits across 5 years are shown in Table (2).
Regarding cottons grown in the Delta, the newly developed lines produced high lint yield with desirable levels of quality, especially the line derived from $10229 \times$ G.86. On the other hand, the newly developed lines growing in Upper Egypt did not surpass Giza 80 and Giza 90, except for lint yield, to some extent. In general, cottons assigned for the Delta showed superiority in lint and yarn quality over cottons devoted to Upper Egypt; whereas, cotton yield was in the same levels. Data obtained in Table 2 showed that there were wide ranges for yield and quality traits of long staple cottons.

The mean and median values are approximately the same for micronaire value and fiber strength, indicating symmetric distribution of these properties. This is not so for lint yield, fiber length and yarn strength, where the differences between mean and median values exhibit skewed positive distribution. The mean squares obtained from analysis of variance showed that differences among cottons for LY, MIC and FS were highly significant, whereas, those for UHM and YS were significant. The effects of years on all characteristics were highly significant. The variances of variety $\times$ year interactions for MIC, FS and YS were significant, but were non significant for LY and UHM.

Despite the variations, some of cottons had uniformity in a sense of trait standards as they could be grouped with extra long fiber length, low MIC and strong fiber, and also some cotton varieties could be grouped with medium fiber 
Table (2): Effect of cotton varieties and years on the means of yield and fiber and yarn quality traits for the long staple category.

\begin{tabular}{|c|c|c|c|c|c|}
\hline Cotton genotypes & $\begin{array}{c}\mathbf{L Y} \\
(\mathbf{K} / \mathbf{F})\end{array}$ & MIC & $\begin{array}{l}\text { UHM } \\
(\mathbf{m m})\end{array}$ & $\begin{array}{c}\text { FS } \\
(\mathrm{g} / \mathrm{tex})\end{array}$ & YS \\
\hline G. 86 & 11.9 & 4.3 & 32.4 & 43.9 & 2470 \\
\hline $10229 \times G .86$ & 15 & 4.1 & 33.5 & 40.5 & 2515 \\
\hline G.89×G.86 & 12.9 & 4.2 & 32.0 & 43.8 & 2480 \\
\hline G.75×Sea & 13.0 & 4.1 & 34.0 & 41.0 & 2435 \\
\hline G.90×Australian & 14.2 & 4.3 & 30.1 & 37.7 & 2015 \\
\hline G.83 $\times(G 75 \times 5844) \times G .80$ & 15.2 & 4.3 & 29.8 & 38.1 & 2010 \\
\hline G. 80 & 11.4 & 4.4 & 31.2 & 39.0 & 2090 \\
\hline G. 90 & 12.5 & 4.3 & 30.0 & 37.7 & 1975 \\
\hline Mean & 13.2 & 4.23 & 31.7 & 40.2 & 2330 \\
\hline Median & 12.5 & 4.3 & 30.4 & 39.5 & 2265 \\
\hline \multicolumn{6}{|l|}{ Mean squares for } \\
\hline Cottons ( V) & $11.16 *$ & $\mathbf{0 . 0 3 9}^{* * *}$ & $1.21^{*}$ & $7.55^{* *}$ & $21582^{*}$ \\
\hline Years (Y) & $8.37^{* *}$ & $\mathbf{0 . 0 7 3}^{* * *}$ & $13.29^{* *}$ & $32^{* *}$ & $204087^{* * *}$ \\
\hline $\mathrm{V} \times \mathrm{Y}$ interactions & $0.999^{\mathrm{ns}}$ & $0.0197^{*}$ & $0.211^{\mathrm{ns}}$ & $1.57 *$ & $17263^{*}$ \\
\hline L.S.D. (0.05) & 0.693 & 0.043 & 0.338 & 0.659 & 45 \\
\hline
\end{tabular}

*, **: significant at $\mathbf{p}<0.05$ and $\mathbf{p}<0.01$ levels, respectively, while ns: non significant.

length, average MIC and strong fiber. It was due to the fact that breeders mostly develop varieties to meet certain common fiber standards and requirements (Bayles et al., 2005 and Rahman et al., 2002).

\subsection{Correlations among yield and quality traits}

The correlation coefficients among lint cotton yield, micronaire value, fiber length, fiber strength and yarn strength of the 14 cotton genotypes across five years are presented in Table (3).

The strongest and highly significant positive correlations are those of fiber length to fiber strength and yarn strength and those of fiber strength with yarn strength. Lint cotton yield showed a low but highly significant and positive correlation with micronaire value, and significant negative correlations with fiber length, fiber strength and yarn strength. Micronaire value showed highly significant and negative correlations with fiber length, fiber strength and yarn strength.

Correlations among yield and fiber quality traits are employed as selection criteria for successful cotton breeding. Fiber length, micronaire and fiber strength were closely and highly significant interrelated, such that cottons with longer fiber had stronger fiber and lower micronaire value. Zhang et al. (2005) and Ulloa \& Meredith (2000) reported similar findings. On the contrary, a positive association was found between fiber fineness and fiber strength (Mei et al., 2004).

The positive and highly significant association of lint yield with micronaire value (Table 3) suggests that any increase in micronaire (high value) may increase lint yield of cotton; whereas, the negative association of lint yield with fiber length and fiber strength suggests that any improvement of these characteristics may decrease cotton yield (Lancon et al., 1993 and Gomma, 1995). The association between yarn strength and micronaire value was negative and highly significant; whereas, the association with fiber length and fiber strength were positive and highly significant, indicating that any improvement in fiber length, fiber strength and micronaire (low value) may increase yarn strength (Killi et al., 2005 and Asif et al., 2008).

Development of cotton varieties with improved fiber traits has been very difficult due to the linkage between genes controlling these traits, which can be avoided using new tools of molecular breeding (Rahman et al., 2002, Jauhar, 2006 and Asif et al., 2008).

Table (3): Simple correlation coefficients among yield and fiber and yarn quality traits for Egyptian cottons.

\begin{tabular}{|c|c|c|c|c|}
\hline & LY & MIC & UHM & FS \\
\hline YS & $-\mathbf{- 0 . 4 6 7}^{*}$ & $-0.711^{* *}$ & $0.912^{* *}$ & $0.924^{* *}$ \\
\hline FS & $-\mathbf{- 0 . 3 8 7}^{*}$ & $-0.582^{* *}$ & $0.790^{* *}$ & \\
\hline UHM & $-\mathbf{- 0 . 4 3 6 *}^{*}$ & $-0.744^{* *}$ & & \\
\hline MIC & $0.599^{* *}$ & & & \\
\hline
\end{tabular}
respectively. 


\section{REFERENCES}

Abdel-Latif H.M., Nassar S.A., Gomaa I.M., Abdel-Aziz N.S. and Solami A.M. (1975).

Effect of genotype - environment interactions on seed cotton yield and lint percent. Agric Res. Rev., 53: 1-9.

Asif M., Mirza J.I. and Zafar Y. (2008). Genetic analysis for fiber quality traits of some cotton genotypes. J. Bot., 40 (3): 1209-1215.

A. S. T. M. (1967). American Society for Testing and Materials. D-1578., Book of ASTM Standards, Part 25. The Society, Philadelphia, PA.

A. S. T. M. (1998). American Society for Testing and Materials. D-1776, Vol. 07, No. 1, Easton, MD, USA.

Bayles M.B, Verhalen L.M., Johnson W.M. and Barnes B.R. (2005). Trends over time among cotton cultivars released by the Oklahoma Agricultural Experiment Station. Crop Sci., 45:966-980.

Bradow J.M. and Davidonis G.H. (2000). Quantization of fiber quality and the cotton production processing interface: A physiologist's perspective. J. Cot. Sci., 4: 3464.

Campbell B.T. and Jones M.A. (2005). Assessment of genotype $\times$ environment interactions for yield and fiber quality in cotton performance trials. Euphytica, 144: 69-78.

Chee P., Draye X., Jiang C.X., Decanini L., Delmonte T., Bredhauer R., Smith C.W. and Paterson A.H. (2005). Molecular dissection of interspecific variation between Gossypium hirsutum and Gossypium barbadense cotton by a backcross-self approach: I. Fiber elongation. Theor. Appl. Genet., 111: 757763.

Estur G. (2004). Quality Requirements on Export Markets for U.S. Cotton. Proc. Beltwide Conf. Jan., 5-9, San Antonio, Tx., USA.

Geng S., Zhang Q.F. and Bassett D.M. (1987). Stability in yield and fiber quality of California cotton. Crop Sci., 27: 1004-1010.

Gomma N.A.M. (1995). Evaluation of some families derived from two Egyptian cotton crosses. Ann. Agric. Sci., (Cairo), 40:153164.
Ismail A.M. and El Sheikh A.H. (1991). The consistency of micronaire reading and its relations with fiber, yarn strength and yield per feddan of the commercial Egyptian cotton. Agric. Res. Rev., 69(60): 2285-2295.

Jauhar P.P. (2006). Modern biotechnology as an integral supplement to conventional plant breeding: The prospects and challenges. Crop Sci., 46: 1841-1859.

Killi F., Lale E. and Sefer M. (2005). Genetic and environmental variability in yield, yield components and lint quality traits of cotton. Int. J. Agric. Biol., 7(6): 1007-1010.

Lancon J.E, Goze B. Hau, Bachelier M. and Chanseline J.L. (1993). Multisite trait of diallel with four elite parents, correlation between four variables. Cotton Fib. Trop., 48: 11-14.

Mei M., Syed N.H., Gao W., Thaxton P.M., Smith C.W., Stelly D.M. and Chen Z.J. (2004). Genetic mapping and QTL analysis of fiber-related traits in cotton (Gossypium). Theor. Appl. Genet., 108: 280-291.

Meredith W.R. (2003). Thirty-six years of regional high quality variety tests. Proc. Beltwide Cotton Conf. Jan., 6-10, Nashville, TN.

Moor J.F. (1996). Cotton classification and quality. PP. 51-57., In. the cotton industry in United States.

Paterson A.H., Saranga Y., Menz M., Jiang C.X. and Wright R.J. (2003). QTL analysis of genotype $\times$ environment interactions affecting cotton fiber quality. Theor. App. Genet., 106: 384-396.

Rahman M., Hussain D. and Zafar Y. (2002). Estimation of genetic divergence among elite cotton cultivars-genotypes by DNA finger printing technology. Crop Sci., 42: 21372144.

Ulloa M. and Merdith W.R. (2000). Genetic linkage map and QTL analysis of agronomic and fiber quality traits in an interspecific population. J. Cot. Sci., 4: 161-170.

Zhang J., Lu Y., Canterll R.G. and Hughs E. (2005). Molecular marker diversity and field performance in commercial cotton cultivars evaluated in the Southwestern USA. Crop Sci., 45: 1483- 1490. 


\section{تقييم محصول و جودة أربعة عشر من الأصناف والسلالات المبشرة من القطن المصرى \\ ابراهيم أحمد محمود عبيدو - "هيام سيد أحمد فاتح - رقية محمود حسان

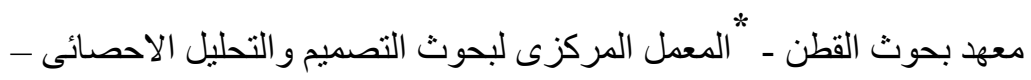

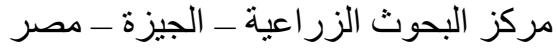

تهدف هذه الدر اسة إلى تقييم محصول القطن الثعروصفات جودة التيلة والغزل لبعض أصناف الأقطان التجارية المصرية

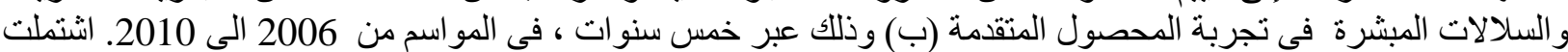

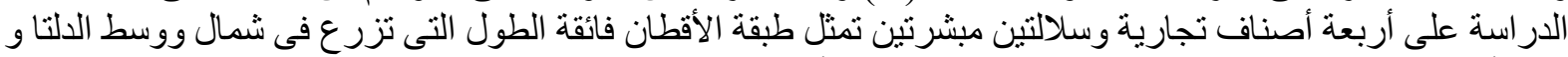

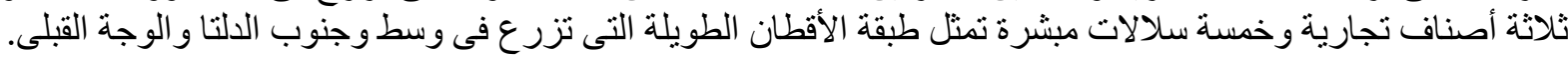

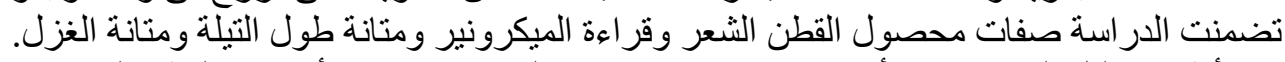

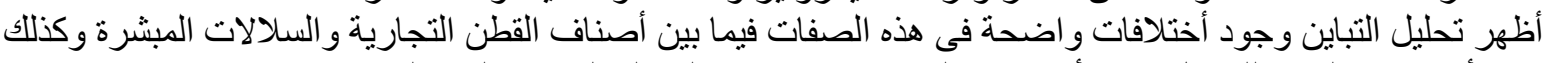

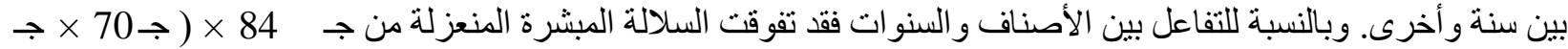

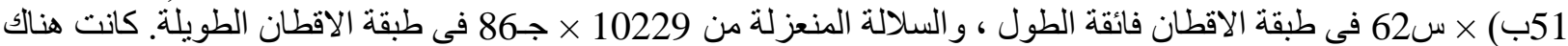

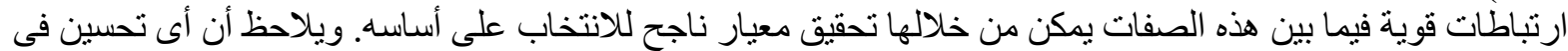

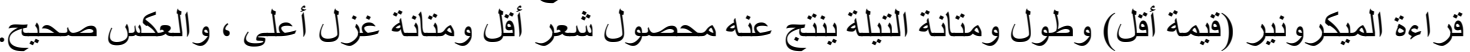

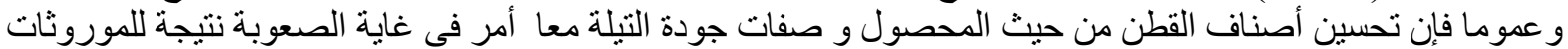

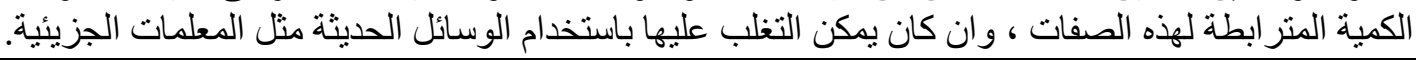

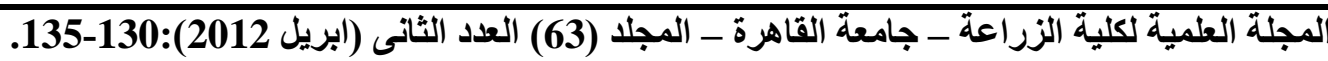

